\title{
RIGHT TO HEALTH IN THE DECISIONS OF THE EUROPEAN COURT OF HUMAN RIGHTS
}

\author{
Vitaliy B. Kovalchuk ${ }^{1}$ Bogdana B. Melnychenko², Kostyantyn B. Marysyuk ${ }^{3}, \mathrm{Na-}$ \\ taliia D. Slotvinska ${ }^{4}$, Mykhailo V. Shulga ${ }^{5}$ \\ Department of Theory and Philosophy of Law, Constitutional and International Law, Institute of Jurisprudence, Psychology and \\ Innovative Education, Lviv Polytechnic National University, Lviv, Ukraine1; Department of Theory and Philosophy of Law, Con- \\ stitutional and International Law, Institute of Jurisprudence, Psychology and Innovative Education, Lviv Polytechnic National \\ University, Lviv, Ukraine2; Department of Criminal Law and Procedure, Institute of Jurisprudence, Psychology and Innovative \\ Education, Lviv Polytechnic National University, Lviv, Ukraine ${ }^{3 ;}$ Department of Criminal Law and Procedure, Institute of Juris- \\ prudence, Psychology and Innovative Education, Lviv Polytechnic National University, Lviv, Ukraine ${ }^{4 ;}$ Department of Land and \\ Agrarian Law, Yaroslav Mudryi National Law University, Kharkiv, Ukraine ${ }^{5}$
}

\section{Abstract}

The article is devoted to the coverage of general theoretical and practical aspects of the protection of the right of a person to health care in the European Court of Human Rights. The substantive and essential correlation of the main elements of protection of the individual's right to health care in the European Court of Human Rights is analysed. Based on the analysis of the norms of international law, the main elements of protection of a person's right to health care have been identified in the European Court of Human Rights. In this study used the formal-logical method, method of analysis, methods of synthesis, generalization, induction, deduction. Analysed the mechanism of the right to health in the European system of human rights. The practical significance of the study of the case law of the ECtHR is that the question of its application is a certain legal guideline for all law enforcement agencies - judges, lawyers, prosecutors, law enforcement officers and other participants.

Keywords: European standards on protection of the right to health, European Convention of Human Rights; right to life; health-care; medical treatment.

\section{INTRODUCTION}

The right to health care is exercised through many others constitutionally enshrined human rights. Health care is a system of measures aimed at ensuring the preservation and development of physiological and psychological functions, optimal performance and social activity of a person for maximum life expectancy. The effectiveness of any inalienable human right is determined by the real results achieved through the application of norms. To achieve the desired results, the state takes legal and organizational measures. It is in the state that conditions are created that ensure the interdependence and interaction of the national legal system and the system of international law, the implementation of international legal standards in national legislation. Consolidating the right to health at the level of European human rights instruments is an important guarantee of the recognition of this right by the world community and places responsibility on the state. State acts and international human rights instruments are the legal basis for the protection of one 
of the fundamental human and civil rights - the right to health.

The urgency of the regulation of the right to health is due to the awareness of it as one of the fundamental human rights in a democratic society. The creation of conditions by the state for the realization of the human right to health is a guarantee of progressive development in various spheres of life and strengthening of national security. The importance of the right to health has given impetus to the active development of a new branch of law - medical law. The problem of protection of the rights of patients and medical workers in recent years has received significant development in foreign and domestic legal literature. This is due to the growing legal awareness of the population, the formation of market relations in most spheres of life, the legal experience of citizens who have been able to defend their human rights, citizens, consumers, the ability to compare the level and quality of care provided in different forms of ownership. Health. The realization of the right to life is not possible without the realization of the right to health. After all, normal biological and social functioning of a person is impossible without health. The full realization of the right to life is possible only with the guarantee of the right to health.

From the case law of the European Court of $\mathrm{Hu}-$ man Rights, we can conclude that the right to health is comprehensive and includes a number of rights: the right to information and the confidentiality of health information; the right to medical and social assistance; the right to consent to treatment and medical intervention; the right to a favourable environmental environment that affects health, etc. Thus, the relationship between the right to health and socio-economic rights is subjective. It is complex in nature, and applies both in the context of the unity of social and biological essence of man. It is therefore very relevant, from a theoretical and practical point of view, to study the implementation of the right to health in the activities of the European Court of Human Rights.
The object of this study is the international relations that arise in the process of realization of the right to health within the framework of regional mechanisms for the protection of human rights. The subject is the realization of the right to health in the activities of the European Court of Human Rights. The purpose of this article is to analyse the case law of the European Court of Human Rights on the exercise of the right to health. This goal determines the following tasks: to identify the features of the realization of the right to health in the European mechanism of human rights protection; to study the mechanism of realization of the right to health in the activity of the European Court of Human Rights; describe the case law of the European Court of Human Rights on the exercise of the right to health.

Many scientific works, including studies of such scholars as M. Behalo /1/, A.M. Kuchuk/2/, G. Mular/3/, J. Murgel/4/, N.V. Sazhienko/5/ are devoted to the issues of the practical application aspects of the ECtHR decisions in law enforcement practice. The purpose of this article is to examine the international regional system of the preservation of the right to health in the European human rights system through the work of the ECtHR, to analyse the case law of the ECHR based on the human right to health. This purpose determines the following tasks: to identify the features of the realization of the right to health in the European mechanism of human rights protection; to study the mechanism of realization of the right to health in the activity of the ECtHR; to describe the case law of the ECtHR in terms of the right to health.

\section{MATERIALS AND METHODS}

Research methods are determined by its purpose and objectives. The study used a dialectical method of cognition that became the basis for the disclosure of the specifics of cases of the European Court of Human Rights, which are related to the protection of the human right to health. The method of analysis-synthesis was used to substantiate the legal positions concerning human rights violations in the field of health care in the decisions of the European Court of Human 
Rights. The formal aspects of the protection of human rights to health are considered in the decisions of the European Court of Human Rights. Formally, the dogmatic method was used to interpret the provisions of international treaties, resolutions of international organizations relating to the protection of human and civil rights to health. The hermeneutic method was used to interpret the provisions of the European Convention on Human Rights relating to the subject of the study. The structural-logical method was used to analyse the necessary amount of information on the role and place of ECtHR decisions in the protection of human and civil rights in the context of the right to health, which should act as a guarantor of such protection in a democratic society.

In addition, we used a method of doctrinal legal research, also called "black letter" methodology, focusing on the law in action. The "black letter" law methology is used to focus attention on conducting research on the letter of the law and the desire to conduct a descriptive analysis of legal norms, based on primary sources. Using this method, we composed a descriptive and detailed analysis of the legal rules found in primary sources (European Convention on Human Rights). The purpose of this method is to gather, organize, and describe the law; provide commentary on the sources used; then, identify and describe the underlying theme or system and how each source of law is connected. Under this approach, we conducted a critical, qualitative analysis of legal materials to support our hypothesis. The empirical method of the research uses data analysis to study legal systems. The process of the empirical research involves four steps: design the project, collect and code the data, analyse the data, determine the best method of presenting the results.

We collected and coded the data by determining the possible sources of information and available collection methods, and then putting the data into a format that can be analysed. We analysed and compared the data to our hypothesis. The study used the ECHR, Thematic report /6/ and Health- related issues /7/ in the case law of the ECtHR. A number of articles related to the research topic were also analysed, such as "Human rights in health care" /8/, "Foreign experience in the functioning of the health care system in the context of the implementation of the right to health care" /9/, "Medical negligence and liability of health professionals in the European court of human rights case law" /10/, "Current issues of protection of the right to health in the case law of the European Court of Human Rights" /11/.

\section{RESULTS}

Human rights in the field of health are based on the standards of the international concept of human rights, many of which are reflected in regional international treaties and national constitutions. They differ from patient rights, which codify specific rights that apply only to patients, but do not apply general human rights standards to all those involved in health care, including health professionals. The concept of human rights in the context of medical care pays attention, for example, to such a phenomenon when many violations in the field of study are explained by "simultaneous and often conflicting responsibilities" of medical workers both in relation to patients and in relation to the state. For example, in modern conditions of development and improvement of the health care system, doctors and patients must cooperate to make joint decisions on diagnosis and treatment. Financial issues are inextricably linked to the quality of health care, which in turn can lead to inequality and discrimination. There is a need to better understand the social determinants of health that run between traditional medicine and the broader concept of the health system, including the relationship between the right to health and the realization of all human rights. A human rights-based approach to health uses the human rights framework to analyse these elements, which include health care. Issues related to human rights in health are highlighted below. This list is far from complete, but it highlights the most problematic issues and vulnerable groups of the population, whose rights are often 
violated during treatment in medical institutions /12/.

All over the world, the European Court of Human Rights has long been a model of justice and the last resort to restore violated rights. Everyone who has lost hope for justice in their country applies to the ECtHR. The significance of ECtHR decisions is difficult to overestimate. For most applicants, the possibility of recourse to the European Court of Human Rights was the only way to combat the imperfections of the national justice system. For practitioners, ECtHR decisions have become the only method for identifying systemic problems and at the same time setting the human rights standards to be pursued.

The European Court of Human Rights is essentially a jurisdiction in the field of human rights protection (Article 32 of the ECHR) /13/. This means that this court deals with all matters concerning the interpretation and application of the Convention and its protocols, as well as with individual disputes concerning human rights violations. An individual complaint about a violation of human rights and freedoms does not require the consent of the state, and the ECtHR itself is not bound by decisions of national courts. The ECtHR finds whether a person's right has been violated in terms of higher standards than national ones. At the same time, decisions of the ECtHR on individual disputes are binding on the member state of the ECHR, and in case of non-compliance, certain sanctions may be applied by the Committee of Ministers of the Council of Europe.

In addition to resolving the merits of an individual dispute, the ECtHR also develops in its decision the very provisions of the Convention, which must be interpreted equally by all States parties to the ECHR. It is this feature of the "duty of uniform interpretation" that allows national courts to refer to ECtHR judgments in individual disputes concerning other States. ECtHR decisions can be described as precedents. And although court precedents are not a source of law in Ukraine, the de facto situation is quite different $/ \mathbf{1 4} /$.
St. 2 of the Convention stipulates that the right to life is protected by law. However, according to the established practice of the ECtHR, this right is considered violated not only in the case of loss of life, but also in case of serious injuries to the human body, which did not cause or death, but posed a serious threat to his life. The state is obliged to protect human life from encroachment, as well as from intentional deprivation of life. In addition, the state is obliged to provide an independent forensic system, which will determine the cause of death if it occurred in a medical institution or if the patient was under constant medical supervision, as well as the degree of responsibility of medical staff. The right to health also includes the provision of necessary medical care in cases where it is necessary. Health protection is not possible without the full provision of medical care, as any delay in a crisis situation can lead to death or serious consequences for a person. Under the Convention, a person has the right to physical and moral integrity. The principle of physical inviolability is that any physical violence that may result in physical harm, physical pain, damage to the physical functions of the body or any other harm to a person's health is prohibited. Another important right concerning the right to health is the right to information and the confidentiality of information provided for in Art. 8 of the Convention.

Everyone has the right to any information about their health, medical services and methods of obtaining them, as well as everything that is available through scientific and technological progress. With regard to the right to receive reliable and timely information about the factors that affect health, individuals and organizations are obliged to report factors that may affect the health of citizens. The case law of the ECtHR also addressed the issue of inadequate information of persons about the state of health and the degree of damage to health, who were exposed to radiation or harmful substances during experiments in the context of Art. 8 of the Convention. In addition to the above, one of the components of the right to health is the right to consent to treatment and medical intervention. 
Ukrainian and international legal acts and moral and ethical documents related to medical activities contain provisions on informed patient consent to medical intervention. The person has the right to refuse medical intervention. Medical intervention, which carries a risk to the patient's health, may be an exception in cases of extreme necessity. There are other rights that are also part of the right to health. A wider list of them is provided by the Fundamentals of the legislation of Ukraine on health care, in which the state also enshrines the right of a citizen of Ukraine to health care and ensures his protection /15/.

The protection of the right to health cannot be exercised without the right to a fair trial, so the case law of the European Court of Human Rights is a confirmation of this. In the case of F. E. v. France of 30 October $1998 / \mathbf{1 6} /$, the case concerned the infection of a patient with HIV through a blood transfusion. The applicant was taken to hospital on 27 October 1985 to have his tonsils removed. During the operation, the surgeon, with the consent of the anesthesiologist, injected him with three portions of fresh plasma and an ampoule of PPSB. Blood tests showed that the applicant's blood components were not normal. He was diagnosed with "infectious mononucleosis". Serological tests for HIV gave positive results. By a decision of October 4, 1991, the chairman of the Colmar court demanded the expert's opinion. In a report of 28 February 1992 the medical expert concluded that there was a strong possibility of a causal link between the administration of the contents of the PRSB ampoule to the applicant and HIV infection. Based on this report, the applicant applied to the Colmar Court, and by a court decision of 25 May 1992 a civil case was instituted in that court against the owners of the hospital, the Health Insurance Fund and the general insurance program of the National Education Service. Dissatisfied with the decisions of the domestic courts, the plaintiff appealed to the ECtHR, substantiating his claim under paragraph 1 of Art. 6 of the Convention. In his complaint, the plaintiff alleged that, having applied to the domestic courts, he had failed to assert his right to compensation for non-pecuniary damage and damage to health. The plaintiff also complained about the length of the proceedings, which lasted more than five years and demanded that the French State violate paragraph 1 of Art. 6 of the Convention, and award him 1 million francs in compensation for pecuniary damage and 1 million francs in compensation for non-pecuniary damage /17/.

The Court carefully analyzed the domestic law of France and the material of all the proceedings instituted by the applicant and concluded as follows: and this amount is a fair additional compensation for the damage caused to the infection. Another important right concerning the right to health is the right to information and the confidentiality of information provided for in Art. 8 of the Convention. The ECtHR judgment in MS v. Sweden of 27 August 1997 /18/ stated that the confidentiality of health information was a fundamental principle of the legal system of the participating States. National legislation should ensure non-disclosure of health information if it does not comply with Art. 8 of the Convention.

In the case of $\mathrm{Z} v$. Finland /19/ The European Court pointed to a violation of Art. 8 of the Convention as regards the disclosure by the Finnish Court of Appeal of the plaintiff's state of health without her consent in the criminal proceedings. Both the plaintiff and her husband were HIVpositive. Also in violation of Art. 8 The European Court of Justice has also recognized the decisions of national courts to keep the materials of this case classified as "confidential" for 10 years. Of interest is the decision of the European Court of Human Rights in the case of Lopez Ostra v. Spain, in which the Court noted that the company's hydrogen sulfide emissions exceeded the permissible level and could endanger the health of the population living in the immediate vicinity of the plant. The ECtHR also noted that the Spanish authorities, and in particular the municipality of Lorca, are not directly responsible for emissions from the plant, but at the same time believes that") and due observance of the applicant's rights to the inviolability of her home, private and family life. Thus, there was a violation of Art. 8 of the Convention". In its judgment in Hutton and 
Others v. The United Kingdom of 8 July 2003 /20/, the ECtHR concluded that the issue of living in contaminated areas and the effects of adverse environmental conditions on the applicants' health fell within the scope of Art. 8 of the Convention $/ 21 /$.

Also in the practice of the ECtHR, the issues of improper informing of persons about the state of health and the degree of damage to health, who were exposed to radiation or harmful substances during experiments in the context of Art. 8 of the Convention. In Roch v. The United Kingdom /22/ the applicant argued that under Art. 8146 of the Convention, the state is obliged to provide him with the right to an accessible and effective procedure for obtaining information on risks and threats to health in connection with experiments concerning the right to respect for private life. The ECtHR in the present case found that the issue of access to such information was closely linked to the applicant's private life, and Art. 8 is applicable. In addition, the ECtHR established a positive obligation on the state to provide such information.

One of the components of the right to health is the right to consent to treatment and medical intervention. In its judgment of 9 March 2004 in Glass v. The United Kingdom /23/, the Court concluded that the decision to grant appropriate treatment to David without his mother's consent was an interference with his right to respect for his private life, in particular his right to physical integrity. . 8 of the Convention. In the judgment of the European Court of Human Rights in the case of Bendersky v. Ukraine of 15 November 2007 /24/, the court cited as an example its practice according to which a person's physical integrity undoubtedly follows from the notion of "private life" within the meaning of Article 1 para. 8. Thus, any task of harming doctors, even the slightest, to the physical integrity of a person entails an interference with the right to respect for private life.

One aspect of exercising the right to health is the failure to provide timely, appropriate and necessary medical care. Victims of failure to provide timely proper and necessary medical care are persons deprived of their liberty, and these actions can be qualified as a violation of Art. 3 of the Convention, which follows from the case law of the Court. In many decisions of the European Court of Human Rights regarding Ukraine's violation of the requirements of Art. 3 of the Convention addressed the issue of failure to provide or timely provision of adequate medical care. Measures that deprive a person of liberty often cause suffering. In a judgment in D. v. The United Kingdom of 2 May $1997 / \mathbf{2 5} /$, the ECtHR ruled that, in the event of the deportation of the plaintiff, Art. 3 of the Convention. The plaintiff in this case had AIDS, was in the United Kingdom and was serving a prison sentence for drug trafficking. Officials have decided to deport him to St. Kitts /26/.

The ECtHR noted in its judgment that the applicant's illness was in a serious condition and that his deportation to the island would undoubtedly hasten his death due to the lack of proper medical care under the prison regime on the island. The ECtHR's judgment read as follows: 3 of the Convention ". In the judgment in the case of Popov v. The Russian Federation of 13 July 2006 /27/, the ECtHR held that under Art. 3 of the Convention, the state is obliged to ensure that the person is in conditions compatible with respect for human dignity, and the methods of implementing such measures should not expose a person to stress, humiliation, anxiety that exceed the permissible level of suffering caused by imprisonment and practical the importance of the applied measures, his health, mental state must be adequately guaranteed, including by providing the necessary medical care.

Also in the judgment in Okhrimenko v. Ukraine of 15 October 2009 /28/, the ECtHR found that keeping the applicant in hospital in handcuffs was also a violation of Art. 3 of the Convention. The applicant, Okhrimenko, applied for release on remand due to his health condition, namely cancer, but was not released from custody and did not undergo a medical examination. After analyzing the ECtHR's practice of protecting the right to health through the exercise of the right to 
prohibit torture. The Court concludes that the failure to provide timely, appropriate and necessary medical care to persons deprived of their liberty is a humiliation for a person who causes concern and exceeds the permissible level of suffering and is interpreted by the Court as torture.

Another important right concerning the right to health is the right to information and the confidentiality of information provided for in Art. 8 of the Convention. In the decision of the European Court of Human Rights in the case of MS v. Sweden of 27 August 1997 /29/ stated that the confidentiality of health information was a fundamental principle of the legal system of the Member States. National legislation should ensure non-disclosure of health information if it does not comply with Art. 8 of the Convention. Of interest is the ECtHR's judgment in Lopez Ostra v. Spain $/ \mathbf{3 0} /$, in which the Court stated that the company's hydrogen sulfide emissions exceeded the permissible level and could endanger the health of the population living in the immediate vicinity of the plant. The ECtHR also noted that the Spanish authorities, and in particular the municipality of Lorca, are not directly responsible for emissions from the plant, but at the same time believes that") and due observance of the applicant's rights to the inviolability of her home, private and family life. Thus, there was a violation of Art. 8 of the Convention " /31/.

The rights of persons deprived of their liberty are violated by any actions or inaction of penitentiary staff that lead to the deterioration of the person's condition. When all national remedies have been exhausted, Art. 3 of the Convention for the Protection of Human Rights and Fundamental Freedoms: "No one shall be subjected to torture or to inhuman or degrading treatment or punishment." The European Court of Human Rights interprets the failure to provide timely medical care or to be held in a room that cannot be intended for treatment, such as degrading treatment or inhuman treatment.

In the case of Aleksanyan v. The Russian Federation $/ 32 /$, the prisoner demanded to be transferred to a hospital specializing in AIDS treatment. The applicant alleged that the prison hospital had been unsuitable for the treatment of his illness. The National Court stated in its judgment that it saw no serious practical obstacles to the applicant's immediate transfer to a specialized medical facility. It is also important to note that the Moscow AIDS Center was ready to accept the applicant for inpatient treatment. In addition, the court found that the applicant had been able to cover most of the costs associated with his treatment. In reaching its decision, the National Court considered that the regime threat it posed at the time (if it existed) was incomparable to the risk to his health. In any case, the security measures taken by the penitentiary body at No.60 Hospital did not appear to be too onerous.

In the present case, the ECtHR stated that the authorities had not shown sufficient concern for the applicant's health. This led to his degradation and created particularly difficult conditions, which led to the applicant's suffering in custody and his imprisonment. In view of all the circumstances of the case, the ECtHR found a violation of Art. 3 of the Convention. In the Logvinenko v. Ukraine case /33/, the applicant suffered from infiltrative tuberculosis of one lung. In February 2000, he was diagnosed with late-stage HIV infection. The applicant's health deteriorated during his detention and imprisonment. The applicant complained to the ECtHR under Art. 3 of the Convention on inadequate conditions of his detention, inadequacy of the medical care provided to him and ill-treatment of the staff of the Correctional Colony No.47. The ECtHR concluded that the applicant's rights under Art. 3 of the Convention due to the fact that the relevant state authorities did not provide the applicant with adequate conditions of detention that would correspond to his state of health, as well as did not provide him with adequate and necessary treatment.

Thus, we can say that the positive obligation of the state under Art. 3 of the Convention for the Protection of Human Rights and Fundamental 
Freedoms is to create appropriate conditions for the provision of medical care to persons in places of detention. In particular, the regularity and regularity of supervision, the availability of a plan of therapeutic measures to treat the prisoner's illness or prevent its complication, instead of eliminating the symptoms; providing public authorities with detailed documentation of a prisoner's state of health and treatment during detention; creating the conditions necessary for the actual implementation of the prescribed treatment. A lawyer who has a seriously ill client who is in prison may be advised to be particularly careful about ensuring his or her right to health care and to prevent it from being violated, and to use all possible means of protection.

\section{DISCUSSION}

Health care is a system of measures aimed at ensuring the preservation and development of physiological and psychological functions, optimal performance and social activity of man at the maximum biologically possible individual life expectancy. Guarantees of human and civil rights and freedoms are a system of specific means by which citizens realize the effective realization of their rights and freedoms, their protection, protection in case of violation. Their main purpose is to provide everyone with equal legal opportunities for the acquisition, realization, protection and defense of subjective rights and freedoms. Thus, guarantees of human rights and freedoms are a set of all factors in the economic, political, state, cultural and other areas that help to fully realize their rights. The right to health care is inherent in man from birth, is exercised every day, is protected by the state and has a system to protect the violated right.

For the first time in the acts of primary law of European integration entities, the right to human health is mentioned in Art. 69 of the Treaty establishing the European Coal and Steel Community (ECSC) /34/, concluded in 1951 by Germany, France, Belgium, the Netherlands, Italy and Luxembourg. That provision states that ECSC Member States shall take measures to eliminate any restrictions on national grounds when recruiting workers in the coal and steel industries who are nationals of Member States who are recognized as qualified in the coal or steel industry. production, subject to restrictions due to the basic requirements of health care and public policy $/ 35 /$.

The next stage of European integration was the conclusion by Germany, France, Belgium, the Netherlands, Italy and Luxembourg in 1957 in Rome of the Treaty establishing the European Atomic Energy Community (Euratom) and the Treaty establishing the European Economic Community (EEC). The Euratom Treaty mentions the health of citizens as an object of legal protection in 15 cases. Moreover, the need to create conditions to eliminate the danger to life and health of citizens is called by the High Contracting Parties one of the reasons for concluding this agreement in its preamble. A separate chapter 3 is devoted to health and safety, according to which the so-called basic standards must be established by the Company Commission to protect the health of employees and citizens as a whole. The basic standards meant the maximum permissible doses compatible with adequate safety, as well as the fundamental principles governing the examination of the health of workers.

According to Art. 96 of the Euratom Treaty, the need to protect public health (along with the requirements of public order and public safety) may give rise to restrictions on the basis of nationality for access to work in the nuclear field. It is easy to see that this ground for restrictions corresponds to the aforementioned ground contained in Art. 69 of the ECSC Treaty.

In general, health care, as a basis for restriction of rights, is found in international treaties and national legislation of states quite often (see, for example, Part 2 of Article 8 of the European Convention for the Protection of Human Rights and Fundamental Freedoms). The treaties concluded in the framework of integration processes in Europe are no exception in this respect, as illustrated particularly well by the 
Treaty establishing the EEC concluded in 1957 /36/.

On the basis of this treaty, a complex and extensive Community governance mechanism and a system of jurisdictional control becomes more active and comprehensive. As an extremely important document for the development of European integration, which laid down the main directions of cooperation between the states in the Community for many years, the Treaty of Rome did not make a significant contribution to empowering integration entities in the field of health. The health of citizens is mentioned in this act in five cases, but each time as a basis for restricting rights that do not confer on the institutions of the Community additional powers in the field of health $/ 37 /$.

It is well known that the effectiveness of the health care system has a strong impact on public health. The main goal of any health care system is to maximize human health at minimal cost. New demographic, epidemiological, and financial challenges increase the need to target health systems to the needs of individuals and communities. Speaking about the realization of a person's right to health care, it is necessary to focus on the main components: access to medical care (availability and timeliness), care process (preventive measures, safe care, coordinated care and employment, patient preferences), administrative efficiency, equity and health outcomes (public health, health and diseaserelated mortality), funding. These components generally determine the level of quality of care and the functioning of the health care system as such. Any medical care must be timely, safe, effective, patient-oriented, fair /38/.

Yes, people often do not receive the necessary medical care, have difficulty paying for the care they receive, and are not always able to obtain appointment information and get emergency care quickly. According to the Organization for Economic Co-operation and Development's Health at First Sight 2019: OECD Indicators report, one in five people in the world reports not seeing a doctor, despite medical needs. Adequate resources for health care are important for a functioning health care system. If health care systems do not provide adequate financial protection, people may not have enough money to pay for medical care or other basic needs. As a result, lack of financial protection can reduce access to health care, undermine health, exacerbate poverty and exacerbate health and socio-economic inequalities. However, the practice of health systems around the world shows that more resources do not lead to better health outcomes, as cost-effectiveness plays an important role /39/.

The cornerstone that helped strengthen European integration, the Maastricht Treaty /40/, gave the European Commission legal powers, particularly in the field of health. This concerned the prevention of diseases, including addiction to psychoactive substances, as well as the dissemination of information and educational programs. In 1993, the Commission's Public Health Action Plan was published, setting out a number of priorities for the Commission's activities: cancer, AIDS, healthy lifestyles, drug addiction, health monitoring, rare diseases, diseases, pollution, accidents and injuries. In 1999, the President of the European Commission, R. Prodi, declared health a priority for the entire Commission, the Directorate for Health and Consumers was established, and the issue of safe products (all against the background of the cow encephalitis epidemic) was declared a key task

In 2000, the EU signed a memorandum with the WHO, which defines such areas of cooperation between the two supranational entities as poverty, EU enlargement, and children's health. In 2002, a program was approved to reduce the risk of disease and other health threats, in particular when crossing borders. The issue of bioterrorism has taken a special place in the modern political discourse of the EU. EU action in the field of health includes anti-smoking decisions - a ban on advertising of alcohol and tobacco products, smoking in public places, etc. An important role in the EU is played by the 
WHO European Office, which has approved the goals of health policy for the region, implements programs in specific areas. The second direction of the EU's influence on national health policy is to encourage the revision of national health care financing systems, which in most Western European countries are based on solidarity social insurance, which redistributes so-called social risks between generations and people with different income levels. The EU also seeks to provide its citizens with access to healthcare in the various countries of the Union, to establish a common compensation mechanism for healthcare provided outside their country of residence, and to create a "free movement of services" /41, 42/.

\section{CONCLUSIONS}

The European Union is paying more and more attention to health issues. This applies both to the prevention of disease, in particular by promoting a healthy lifestyle and reducing the risks of communicable diseases when crossing borders, and to ensuring that EU citizens have access to healthcare outside their country of residence. The latter envisages a revision of the system of financing health care, which in most European countries is provided by compulsory health social insurance (in view of this, in all post-socialist countries that joined the EU, abandoned the budget model of health care and switched to insurance, which is due not so much to economic as ideological factors).

The European Court of Human Rights only protects social rights indirectly. The European Court of Human Rights in its decisions does not emphasize the violation of social rights, but states the fact of violation of the rights protected by the 1950 Convention. Violation of socio-economic rights (right to health) is considered by the European Court of Human Rights as a circumstance violation of the rights guaranteed by the 1950 Convention. The case law of the European Court of Human Rights shows the relationship between socio-economic rights and civil rights and suggests the need to increase the level of protection of socio-economic rights.
The right to health is included in the catalog of the most important universally recognized human rights and is most often considered as an integral part of socio-economic human rights, but there is no special universal or regional mechanism for protecting this category of rights. The mechanisms for its implementation are insufficiently effective both at the international and national levels. The European Convention for the Protection of Human Rights and Fundamental Freedoms of 1950 (ECHR, Convention) provides a mechanism for the protection and implementation of enshrined rights and freedoms through the activities of the European Court of Human Rights (ECtHR). The right to health is not directly protected by the 1950 Convention, as well as other socioeconomic rights, but recourse to the protection of this right is possible under a number of articles of the 1950 Convention and such practice of the European Court of Human Rights exists, for example, in violation of law for life (art. 2), prohibition of torture (art. 3), right to liberty and security of person (art. 5), right to a fair trial (art. 6), respect for private and family life, inviolability of home (art. 8). The right to health is also regulated by Art. 11 and 13 of the European Social Charter (revised) of 3 May 1996. In Recommendation "The future of the European Social Charter", the Parliamentary Assembly of the Council of Europe emphasized the possibility of strengthening the legal protection of social rights by extending the jurisdiction of the European Court of Human Rights.

The realization of the right to life is not possible without the realization of the right to health. After all, the normal biological and social functioning of man is not possible without health. The full realization of the right to life is possible only with the guarantee of the right to health. The right to life is protected in Art. 2 of the Convention. At the same time, according to the established practice of the ECtHR, this right is considered violated not only in the case of deprivation of life, but also in the case of serious injuries that did not cause his death, but posed a serious threat to his life. The state must not only refrain from intentionally depriving a person of life, but also adhere to a positive obligation to protect human life from 
encroachment by third parties or from the risk of illness that may result in death. However, such an interpretation may be applied only in exceptional cases, taking into account the degree and nature of the damage caused to the person.

The positive obligation of the state is to protect human life and to have an effective independent forensic system, which allows to determine the cause of death if it occurred in a hospital or if the patient was under constant and effective medical supervision, and the degree of responsibility of medical staff. In Art. 2 of the Convention stipulates minimum procedural requirements according to which, in cases where the State or its representatives are potentially responsible for the death of a person, the circumstances of doubt must be the subject of an effective investigation or careful study to bring the facts to the public's attention. first of all inform relatives. If there is no indication that the authorities have arbitrarily assessed the evidence presented, the ECtHR may rely on the facts established by the national authorities. In the judgment in the case of Calvelli and Chilo v. Italy, the ECtHR ruled that deaths due to medical intervention by the State, in accordance with Art. 2 of the Convention, should provide for regulations that oblige public and private health care facilities: to take measures to protect the lives of patients; in the event of a hypothetical fault on the part of health workers, ensure that the cause of death is established through an effective independent judiciary so that the perpetrators can be brought to justice.

Ensuring medical confidentiality is also an important aspect of exercising the right to health. The right to secrecy is a fundamental personal intangible right of an individual. The realization of the right under study is provided by a number of guarantees, which are manifested primarily in the observance of special responsibilities imposed on others. At the same time, it is crucial not only to respect the patient's medical secrecy and protect the patient's privacy, but also to ensure his trust in medical staff, the medical profession and medical services in general.
Even during the trial, the court must respect and not violate a person's right to keep information about his or her health confidential. Thus, in Panteleenko v. Ukraine (application no. 11901/02), on 29 June 2006 the European Court of Human Rights stated that disclosure of information about a person's mental health during a court hearing was not recognized as lawful. The ECtHR found that the court of national jurisdiction had exaggerated its powers by requesting a psychiatric hospital for information that was not directly relevant to the case and did not affect the outcome of its proceedings. In addition, despite clear requirements for the storage of documents containing information about the mental health of a person and the provision of psychiatric care in compliance with the conditions that guarantee the confidentiality of this information, the court announced the results obtained from the psychiatric clinic in open court. , thus, information about the mental health of the applicant in the past, and thus violated the provisions of Art. 8 of the Convention for the second time.

Based on the case law of the European Court of Human Rights, we can say that the right to health is generalized, which consists of the following parts: the right to information and confidentiality of information about health; the right to medical and social assistance; the right to consent to treatment and medical intervention; the right to a favorable environmental environment that affects health, etc. Thus, the relationship between the right to health and socio-economic rights is subjective. The Constitution of Ukraine also points to the equality of citizens in their freedoms and rights. They are inalienable and inviolable. The right to life basically includes the right to health. The law defines health as a state of complete physical, mental and social well-being and not merely the absence of disease or infirmity. Only by guaranteeing the right to health can a person exercise his right to life in full. The European Court of Human Rights protects social rights. However, the European Court of Human Rights in its decisions does not emphasize the violation of social rights, but states the fact of violation of rights. 
Notes

/1/ Behalo, M. (2020), The right of prisoners to treatment: the case law of the European Court of Human Rights. Retrieved from https://yurgazeta.com/publications/practice/sudovapraktika/pravo-uvyaznenih-na-likuvannyapraktika-espl--.html

/2/ Kuchuk, A.M. (2020), Human rights in health care. Scientific Bulletin of Dnipropetrovsk State University of Internal Affairs, 1, 15-20.

/3/ Mular, G. (2020), Foreign experience in the functioning of the health care system in the context of the implementation of the right to health care. Bulletin of the APSVT, 1-2, 43-52.

/4/ Murgel, J. (2020), Medical negligence and liability of health professionals in the European court of human rights case law, Medicine, Law E Society, 13, 21-44.

/5/ Sazhienko, N.V. (2020), Current issues of protection of the right to health in the case law of the European Court of Human Rights. Retrieved from

http://dspace.onua.edu.ua/bitstream/handle/11

300/9618/Sazhiienko\%20449-

461.pdf?sequence $=1$

/6/ Council of Europe. (2020), Factsheet - Health. Retrieved from https://www.echr.coe.int/documents/fs_health_eng.pdf

/7/ European Court of Human Rights. (2015), Healthrelated issues in the case-law of the European Court of Human Rights. Thematic report. Retrieved from https://www.echr.coe.int/Documents/Research_report_health.pdf

/8/ op. cit. in /2/

/9/ op. cit. in /3/

/10/ op. cit. in /4/

/11/ op. cit. in /5/

/12/ Scott Fitzgerald, F. (2015), Human rights in the field of health protection. Center for Health and Human Rights: F.-K. Bath and the Open Society Foundation.

/13/ Council of Europe. (1950), Convention for the Protection of Human Rights and Fundamental Freedoms. Retrieved from https://rm.coe.int/1680063765 ]

/14/ op. cit. in /6/

/15/ Fedchishin, A.V. (2017), Protection of the right to health care in the European Court of Human Rights. Proceedings of the International Legal Scientific and Practical Conference, 1, 45-47.

/16/ The European Court of Human Rights. (1988), Case of F.E. v. France. Application no. 38212/97.
Retrieved

from https://www.tandfonline.com/doi/abs/10.1080/ 13642989908406825?journalCode=fjhr20

/17/ op. cit. in /7/

/18/ The European Court of Human Rights. (1997), MS v. Sweden. Application no. 74/1996/693/885. Retrieved from https://hudoc.echr.coe.int/eng\#\{\%22tabview $\% 2$ 2:[\%22document $\% 22], \% 22$ itemid $\% 22:[\% 22001-$ $58177 \% 22]\}$

/19/ The European Court of Human Rights. (1997), Z v. Finland. Application no. 22009/93. Retrieved from

https://hudoc.echr.coe.int/eng\#\{\%22fulltext $\% 22$ :[\%22Z\%20v.\%20Finland\%22],\%22documentco llectionid2\%22:[\%22GRANDCHAMBER\%22,\% 22CHAMBER\%22],\%22itemid\%22:[\%22001$58033 \% 22]\}$

/20/ The European Court of Human Rights. (2003), Hutton and Others v. The United Kingdom. Application no. 36022/97. Retrieved from https://www.ecolex.org/details/courtdecision/hatton-and-others-v-the-unitedkingdom-c2aa65b0-5301-4a07-89f937e579bd89d4/

/21/ European Union. (2010), Charter of Fundamental Rights of the European Union. Retrieved from https://www.europarl.europa.eu/charter/pdf/text_en.pdf

/22/ The European Court of Human Rights. (2005), Roch v. The United Kingdom. Application no. 32555/96. Retrieved from https:/hudoc.echr.coe.int/app/conversion/pdf/?library $=$ ECHR\&id=002-3662\&filename $=002$ 3662.pdf

/23/ The European Court of Human Rights. (2003), Glass v. The United Kingdom. Application no. 61827/00. Retrieved from https:/hudoc.echr.coe.int/app/conversion/pdf/?library=ECHR\&id=002-4464\&

/24/ The European Court of Human Rights. (2007), Bendersky v. Ukraine. Application no. 22750//02. Retrieved from https:/hudoc.echr.coe.int/rus\#\{\%22itemid\%22:[\%22001$171889 \% 22]\}$

/25/ The European Court of Human Rights. (1997), D. v. The United Kingdom. Application no. 30240/96. Retrieved from https://www.google.com/search?q=D.+v.+The+ United+Kingdom+of+2+May+1997\&oq=D.+v.+The+United+ 


\section{King-}

dom+of+2+May+1997\&aqs=chrome..69i57.562j0

j4\&sourceid=chrome\&ie=UTF-8

/26/ Office of the High Commissioner for Human Rights. (2008), The right to health. Retrieved from https://www.ohchr.org/documents/publications/factsheet31.pdf

/27/ The European Court of Human Rights. (2005), Popov v. The Russian Federation. Application no. 2217/2012. Retrieved from https:/hudoc.echr.coe.int/fre\#\%7B\%22display\%22:[2],\%22itemid\%22:[\%22002$3205 \% 22] \% 7 \mathrm{D}$

/28/ The European Court of Human Rights. (2009), Okhrimenko v. Ukraine. Application no. 53896/07. Retrieved from https://hudoc.echr.coe.int/eng $\sharp\{22$ tab-

view $\% 22:[\% 22$ document $\% 22], \% 22$ itemid $\% 22:[\% 22001$ 204129\%22]\}

/29/ The European Court of Human Rights. (1997), MS v. Sweden. Application no. 74/1996/693/885. Retrieved from http://www.tandfonline.com/doi/pdf/10.1080/1 3642989708406703\#: :text=In\%20a\%20judgment\%20delivered $\% 20$ at, that $\% 20$ there $\% 20$ had $\% 20$ been $\% 20$ n o

130/ The European Court of Human Rights. (1990), Lopez Ostra v. Spain. Application no. 41/1993/436/515. Retrieved from https://www.escr-net.org/caselaw/2008/lopezostra-vs-spain-application-no-1679890

/31/ op. cit. in /5/

/32/ The European Court of Human Rights. (2008), Aleksanyan v. The Russian Federation. Application no. 46468/06. Retrieved from https:/hudoc.echr.coe.int/eng\#\{\%22fulltext $\% 22$ :[\%22Aleksanyan\%20v.\%20The\%20Russian\%20Federation $\% 22], \% 22$ documentcollectionid2\%22:[\%22GRANDCHAMBER\%22,\%22 CHAMBER\%22],\%22itemid\%22:[\%2200190390\%22]\}
/33/ The European Court of Human Rights. (2007), Logvinenko v. Ukraine. Application no. 15825/06. Retrieved from http:/hudoc.echr.coe.int/app/conversion/docx/pdf?library $=$ ECHR\&id $=001-$

201811\&file-

name $=$ CASE $\% 20 O F \% 20$ GERASIN $\% 20 v . \% 20 U$

KRAINE\%20-

$\% 20 \% 5 B U k r a i n i a n \% 20$ Transla-

tion $\% 5$ D $\% 20$ by $\% 20$ the $\% 20$ Minis-

try\%20of\%20Jus-

tice $\% 20$ of $\% 20$ Ukraine.pdf\&logEvent=False

134/ European Coal and Steel Community. (1951), Treaty establishing the European Coal and Steel Community. Retrieved from https://eur-lex.europa.eu/legal-content/EN/TXT/?uri=legissum:xy0022

/35/ op. cit. in /2/

/36/ op. cit. in /4/

/37/ Ukrainian law. (2016), The right to health in the regulations of the European Union. Retrieved from

https://ukrainepravo.com/international_law/eu ropean_union_law/pravo-na-zdorov-ya-unormatyvnykh-aktakh-evropeys $\% 60$ kogosoyuzu/

/38/ Shvets, Yu. (2018), Features of protection of the right to health care in the European Court of Human Rights, National Legal Journal: Theory and Practice, 1, 56-58.

/39/ op. cit. in /3/

/40/ European Union. (1992), Treaty on European Union. Retrieved from https://europa.eu/european-union/sites/default/files/docs/body/treaty_on_european_union_en.pdf

/41/ Smigina, T. (2018), Global health and the European agenda. Political Management, 1-2, 112-120.

/42/ Getman, A. P., \& Karasiuk, V. V. (2014), A crowdsourcing approach to building a legal ontology from text. Artificial Intelligence and Law, 22(3), 313-335. 